\title{
Return on investment of apprenticeship systems for enterprises: Evidence from cost-benefit analyses
}

\author{
Samuel Muehlemann ${ }^{1,3}$ and Stefan C Wolter ${ }^{2,3^{*}}$
}

* Correspondence:
Stefan.wolter@vwi.unibe.ch
${ }^{2}$ University of Bern, CESifo, Bern,
Switzerland
${ }^{3}$ IZA - Institute for the Study of
Labor, Bonn, Germany
Full list of author information is
available at the end of the article

\begin{abstract}
A firm's decision to engage in apprenticeship training is to a large extent determined by the cost-benefit ratio of such an investment compared to other alternatives of securing skilled workers. Empirical evidence shows that in a well-functioning apprenticeship training system, a large share of training firms can recoup their training investments by the end of the training period. As training firms often succeed in retaining the most suitable apprentices, offering apprenticeships is an attractive strategy to recruit their future skilled work force. In addition - as long as skills are standardised and nationally certified - those apprentices leaving the training firm after graduation ensure that other firms can recruit a sufficient number of skilled workers from the labour market. Firms themselves can influence the cost-benefit ratio of training to some extent, but an equally important or even bigger part of this ratio is determined by public policy: the educational system, training regulations and labour market institutions. To assess the efficacy and efficiency of such framework conditions in regard to the apprenticeship training system, their impact on the cost-benefit ratio of training for firms needs to be assessed ex ante as well as ex post. Unfortunately, so far only two countries (Germany and Switzerland) provide representative and periodic data on the costs and benefits of apprenticeship training that are suitable for such an analysis. Given the importance of adequate data to guide public policy, there is first of all a need for a stronger investment in data collection and data analyses.
\end{abstract}

JEL-Codes: I2, J24, J31.

Keywords: Cost-benefit analyses; Apprenticeship training

\section{Introduction}

Apprenticeship training comes in many different forms. In Europe, many countries have a type of apprenticeship programme that combines education in school and in the workplace. While a portion of apprenticeship models are predominantly schoolbased and only feature short work placements, other models require apprentices to spend up to 80 per cent of their time with the training firm ${ }^{1}$.

Obviously, a firm's costs associated with the training provided in the workplace not only increase with the length of the work placement but also with the intensity of the training provided during the work placement (as defined by training regulations). While a firm may find it less costly to provide firm-specific skills that can be learned on the job without much interruption of the production process, teaching apprentices

(C) 2014 Muehlemann and Wolter; licensee Springer. This is an Open Access article distributed under the terms of the Creative Commons Attribution License (http://creativecommons.org/licenses/by/4.0), which permits unrestricted use, distribution, and reproduction in any medium, provided the original work is properly credited. 
more general skills may be more costly. Nonetheless, depending on the duration of an apprenticeship, firms may well benefit from an increased skill level on the part of their apprentices because it raises their productivity toward the end of the training period.

However, apprentices typically also receive pay that (partially) compensates for their productive contribution. Consequently, the pay structure within firms and imposed minimum wages for apprentices are highly important when calculating the costs and benefits to a firm from training apprentices. Although high apprentice pay makes an apprenticeship more attractive for youth than school-based education (because it lowers the opportunity costs of acquiring education), high apprentice pay lowers a firm's incentives to provide high quality training that goes beyond providing merely the firm-specific skills necessary to perform work within the firm. Accepting low apprentice pay may still be an attractive way for young people to finance their education, as long as training regulations are defined such that apprenticeship training provides sufficient general skills that are nationally certified and therefore valued by many other firms. Put differently, as long as apprenticeship training results in a sufficiently high rate of return to education, low apprentice pay may serve as an efficient device to privately finance education, rather than serving as an indicator of apprentice exploitation.

Thus, depending on where most of the training takes place (in the firm or at school) and the extent to which apprentices are reimbursed for the value of their productive work, the financing scheme for a particular apprenticeship system varies accordingly. In a number of European countries with apprenticeship systems, the expenses related to apprenticeship training are borne entirely by the government, or similarly, governments reimburse firms for their expenses during the time that apprentices are in work placements. ${ }^{2}$ In other countries, particularly when apprentices spend more time in work placements, the private sector makes substantial investments in apprenticeship training but also expects corresponding returns on its investments. In the parts of this paper where we will illustrate our arguments with empirical data, we have to heavily rely on data collected in Germany and Switzerland for the simple reason that representative data on the costs and benefits of apprenticeship only exist for these two countries ${ }^{3}$.

In the remainder of this article, we will discuss the different components of training costs and what types of training benefits a firm can expect, taking into account important external factors that influence the profitability of apprenticeship training and thereby also considering a firm's training strategy and behaviour.

\section{Measuring the net benefits of apprenticeship training}

Apprenticeship training - from the firm's perspective - may result in net costs or net benefits by the end of the training period. Depending on a firm's environment (labour market regulations and competition and social partner agreements), generating a net benefit from training may be a necessary condition to offer apprenticeships. However, if a firm can expect a sufficiently high subsequent return on its training investment (by retaining apprentices as skilled workers), a firm may well be willing to make a net investment in apprenticeship training.

In this section, we provide a brief overview of the cost-benefit model and summary of the main results of existing firm-level studies on apprenticeships in European countries. Moreover, we discuss the potential long-term benefits for firms that offer 
apprenticeships (e.g., reduced recruitment costs for skilled workers) and circumstances under which a firm is most likely to be able to internalise such benefits.

\section{The cost-benefit model}

The systematic measurement of the costs and benefits associated with providing apprenticeship training dates back to the 1970s (see Wolter 2008). While the surveys' initial focus was solely on capturing a firm's training investment, subsequent surveys include a much broader array of questions that go beyond training costs, including a firm's training benefits in the short-run (i.e., the value of an apprentice's productive work) and more long-term benefits (e.g., lower costs for the future recruitment of skilled workers), as well as detailed characteristics about training and non-training firms or indicators of the quality of apprentices.

A firm's costs of apprenticeship training broadly consist of the following categories:

1. Wages of apprentices: regular wage payments, irregular wage payments, compensation for food, travel costs or living expenditures.

2. Costs for training personnel: costs for full-time, part-time and external training personnel for the period in which they were unable to work productively because they instructed apprentices.

3. Recruitment and administrative costs: wage costs for administrative tasks and recruitment related to apprenticeship training.

4. Cost for infrastructure: machinery/appliances for apprentices at the workplace, rent for premises necessary for apprenticeship training, cost of premises and infrastructure for company training centres.

5. Cost for supplies: cost of supplies used for non-productive activities in the workplace, cost of books, learning software and videos, costs of working equipment.

6. Other costs: costs of fees (e.g., exams), capital costs for recruitment/administration related to apprenticeship training, costs of external courses, duties and taxes to third parties.

Training benefits to the firm for the apprenticeship period are given by the value of apprentices' productive work, which is typically divided into skilled and unskilled tasks:

1. The value of having apprentices perform skilled tasks is calculated as the time that apprentices spend on such tasks, multiplied by the wage that a firm would need to pay skilled workers if no apprentices had been hired. That value, however, is further multiplied by the productivity of an apprentice relative to that of a skilled worker ${ }^{4}$.

2. For unskilled tasks, the value to the firm from having an apprentice perform such work is simply the wage that the firm would have had to pay to employ an unskilled worker.

Ultimately, the difference between the costs and benefits of training results in net benefits (or net costs) for the firm.

\section{Descriptive statistics on the costs and benefits of training}

In this section, we briefly review the existing evidence on the costs and benefits of apprentice training - which is, however, very limited. Most recent and large-scale surveys 
were conducted in Germany and Switzerland, the two countries in Europe where firms are most involved in apprenticeship training (Figure 1), but there is also, albeit either older or not representative, evidence for Austria and the United Kingdom. Data from the Netherlands only cover the cost side (see Table 1).

\section{Germany}

In Germany, nearly $90 \%$ of training firms were traditionally willing to bear substantial net costs up to the year 2000 (Beicht et al. 2004). ${ }^{5}$ However, the most recent costbenefit survey in 2007 indicates a significant decrease in net training costs across many occupations (Schönfeld et al. 2010). Although $70 \%$ of all firms continue to incur net costs by the end of the training period, average net costs dropped by $36 \%$, primarily because apprentices were used more extensively for productive activities in 2007 than in 2000 (cf. Pfeifer et al. 2009, Jansen et al. 2012). Thus, while German training firms on average still make net investments in apprenticeship training, there is now a significant share of training firms (30\%) for which apprenticeships are in fact profitable. Although firms who recoup their training investments by the end of training no longer need to rely on retaining their apprentices for financial reasons, the overall retention rate of apprentices (i.e., the share of apprentices that remains with the firm as skilled workers after training) in Germany remained at a high level (slightly above 50\%).

\section{Switzerland}

Schweri et al. (2003) conducted the first detailed and representative Swiss survey (comparable to the German survey) in 2000. Contrary to the situation in Germany at the time, Swiss firms on average generated a net benefit (negative net costs) from training apprentices. This finding was confirmed by two subsequent surveys in 2004 and 2009 (Muehlemann et al. 2007a; Strupler and Wolter 2012, respectively). ${ }^{6}$ More than $60 \%$ of

\begin{tabular}{|c|c|c|c|c|}
\hline \multicolumn{5}{|c|}{$\begin{array}{l}\text { Level of investment by firms* in upper secondary VET programmes } \\
\text { with a work-based component (low, medium, high) (horizontal axis) } \\
\text { relative to the share of students (low, medium, high) enrolled in these programmes (vertical axis) }\end{array}$} \\
\hline \multirow[b]{2}{*}{$\begin{array}{l}\text { Share of dual/part-time } \\
\text { VET to all pupils }\end{array}$} & \multicolumn{4}{|c|}{ Importance of investment by firms } \\
\hline & LOW & MEDIUM & HIGH & \\
\hline $\begin{array}{c}\text { HIGH } \\
(>\mathbf{3 0} \%)\end{array}$ & $\begin{array}{l}\text { the Czech Republic, } \\
\text { Denmark, Estonia }\end{array}$ & Austria & Germany, Switzerland & \\
\hline $\begin{array}{l}\text { MEDIUM } \\
(6-30 \%)\end{array}$ & $\begin{array}{l}\text { Australia, Finland, } \\
\text { Iceland, Norway, } \\
\text { the Slovak Republic }\end{array}$ & $\begin{array}{l}\text { France, Hungary } \\
\text { Luxembourg, } \\
\text { the Netherlands, } \\
\text { the Russian Federation, } \\
\text { the United Kingdom }\end{array}$ & & \\
\hline $\begin{array}{l}\text { LOW } \\
(<6 \%)\end{array}$ & $\begin{array}{l}\text { Belgium, Brazil, } \\
\text { Canada, Chile, Greece, } \\
\text { Ireland, Israel, Italy, } \\
\text { Japan, Korea, Mexico, } \\
\text { New Zealand, Poland, } \\
\text { Portugal, Slovenia, } \\
\text { Spain, Sweden, Turkey } \\
\text { and the United States }\end{array}$ & & & \\
\hline \multicolumn{5}{|c|}{$\begin{array}{l}\text { "The importance of investment by firms is an index that reflects the time that trainees spend in the workplace, the intensity of training } \\
\text { (weekly instruction time) at the workplace, and controls for public reimbursement of such expenditure. }\end{array}$} \\
\hline \multicolumn{5}{|c|}{$\begin{array}{l}\text { igure } 1 \text { Importance of firm investments in OECD countries. Source: OECD Education at a Glance } \\
011, \text { p. } 235 .\end{array}$} \\
\hline
\end{tabular}




\begin{tabular}{|c|c|c|c|c|c|c|}
\hline Country & Authors & $\begin{array}{l}\text { Year of } \\
\text { survey }\end{array}$ & Data & Net costs & $\begin{array}{l}\text { Share of } \\
\text { firms with } \\
\text { net costs }\end{array}$ & $\begin{array}{l}\text { Fraction of } \\
\text { retained } \\
\text { apprentices } \\
(1 \mathrm{yr} \text { after } \\
\text { training) }\end{array}$ \\
\hline \multirow[t]{2}{*}{$\overline{\text { GER }}$} & $\begin{array}{l}\text { Beicht et al. } \\
(2004)\end{array}$ & 2000 & $\begin{array}{l}\text { Representative study } \\
\text { based on } 2424 \text { personal } \\
\text { interviews. }\end{array}$ & $€ 6033^{*}$ & $88 \%$ & $53 \%$ \\
\hline & $\begin{array}{l}\text { Schönfeld } \\
\text { et al. (2010) }\end{array}$ & 2007 & $\begin{array}{l}\text { Representative study } \\
\text { based on } 2986 \text { personal } \\
\text { interviews. }\end{array}$ & $€ 3596$ & $70 \%$ & $53 \%$ \\
\hline \multirow[t]{3}{*}{$\mathrm{CH}$} & $\begin{array}{l}\text { Schweri } \\
\text { et al. (2003) }\end{array}$ & 2000 & $\begin{array}{l}\text { Representative study } \\
\text { based on } 2352 \text { postal } \\
\text { questionnaires. }\end{array}$ & CHF -2900 & $40 \%$ & $36 \%$ \\
\hline & $\begin{array}{l}\text { Muehlemann } \\
\text { et al. (2007a) }\end{array}$ & 2004 & $\begin{array}{l}\text { Representative study } \\
\text { based on } 2413 \text { postal } \\
\text { questionnaires. }\end{array}$ & $\mathrm{CHF}-1700$ & $37 \%$ & $37 \%$ \\
\hline & $\begin{array}{l}\text { Strupler and } \\
\text { Wolter (2012) }\end{array}$ & 2009 & $\begin{array}{l}\text { Representative study } \\
\text { based on } 2413 \text { postal } \\
\text { questionnaires. }\end{array}$ & CHF -3200 & $29 \%$ & $35 \%$ \\
\hline AUT & $\begin{array}{l}\text { Lassnigg and } \\
\text { Steiner } 1997\end{array}$ & 1995 & $\begin{array}{l}\text { Representative study } \\
\text { based on } 1085 \text { personal } \\
\text { interviews. }\end{array}$ & $\begin{array}{l}\text { ATS } 40,000 \\
\text { (net equivalence } \\
\text { costs) }\end{array}$ & $65 \%$ & $\mathrm{n} / \mathrm{a}$ \\
\hline UK & $\begin{array}{l}\text { Gambin } \\
\text { et al. (2010) }\end{array}$ & $2007 / 08$ & $\begin{array}{l}\text { Non-representative study } \\
\text { based on } 42 \text { interviews of } \\
\text { firms in } 5 \text { sectors. }\end{array}$ & $£ 1200-7190$ & $\begin{array}{l}100 \% \text { ( } \mathrm{n} / \mathrm{a} \\
\text { for business } \\
\text { administr.) }\end{array}$ & $\mathrm{n} / \mathrm{a}$ \\
\hline
\end{tabular}

Notes: * based on the same calculation method as in the 2007 survey.

all firms find offering apprenticeships profitable, meaning that the average firm does not need to recoup training expenses after the end of an apprenticeship. The relatively high mobility of Swiss apprentices after training is consistent with this observation: the surveys reveal that more than $60 \%$ of all apprentices leave the training firm within the first year.

\section{Austria}

Lassnigg and Steiner (1997) reported that apprenticeship training in Austria on average resulted in net costs from the perspective of the training firm. However, approximately $35 \%$ of all firms in Austria were able to generate a net benefit from training apprentices.

\section{United Kingdom}

Gambin et al. (2010) analyse case studies in the United Kingdom and find positive net costs associated with apprenticeship training in each of the five sectors that they investigate. However, they show that a firm's net investment may be recouped rather quickly if the training firm can employ former apprentices for at least one to three years.

\section{Long-term benefits from saved resources due to not having to recruit skilled workers on} the external labour market

An additional benefit from training apprentices can be measured by saved future recruitment costs (Stevens 1994b), i.e., the costs a firm faces when searching for and training workers from the external labour market until they reach full productivity. Firms frequently have to hire new workers, either to fill a vacancy or to expand their 
workforce. However, finding a suitable worker who matches the job profile and other possible requirements may be costly. While recruitment and training costs may depend on the general availability of skilled workers on the external labour market, long-term predictions for Europe suggest that there will be a shortage of skilled workers with intermediate skills in many countries despite the currently high unemployment rates (due to the demographic ageing of societies). Thus, apprenticeships may provide a less costly alternative for firms, reducing the need to spend time and effort to find suitable workers externally and training them for their firm-specific needs at the pay level of skilled workers.

While from a theoretical perspective it is clear that firms can save on hiring costs when recruiting former apprentices, the empirical evidence on the magnitude of hiring costs for skilled workers in Europe is rather scarce. The existing studies on hiring costs are summarised in Table 2. In terms of hiring costs as a percentage of monthly pay, German and Swiss firms find it most expensive to fill a vacancy. The costs for advertising a vacancy, conducting and processing interviews and the value of lost production until a new hire reaches full productivity are roughly two months of wage payments in Germany and ten weeks of wage payments in Switzerland. Hiring costs appear to be somewhat lower in the United Kingdom.

The amount of resources a firm spends on new hires may also be reflected in average turnover at the firm level. Firms that invest more in the recruitment process may be more likely to have lower turnover rates, and vice versa. Thus, another important figure is the relationship between hiring costs and the annual wage bill. For most worker categories, hiring costs range from $2 \%$ to $5 \%$ of the annual wage bill (with the exception of hires in sales in the UK, cf. Manning 2006). Thus, turnover costs constitute an economically substantial component of total labour costs, which may be (partly) reduced by apprenticeship training.

While high hiring costs for skilled workers are a potential source of benefits from apprenticeship training, firms need to be able to successfully retain their apprentices to be able to reap these (recrutive opportunity) benefits. Generally, the turnover rates of employees correlate with the overall frictions in a (local) labour market. Thus, a training firm will be more likely to retain a high share of former apprentices in countries or regions with a low degree of worker mobility. While there are many factors that determine the mobility of employees, two important reasons are: (i) the number of potential

Table 2 Hiring costs in Europe

\begin{tabular}{|c|c|c|c|c|}
\hline Study & Country & Costs & $\begin{array}{c}\text { Hiring costs as } \\
\text { percentage of wage bill }\end{array}$ & $\begin{array}{c}\text { Hiring costs as } \\
\text { percentage of } \\
\text { monthly pay }\end{array}$ \\
\hline Manning (2006) & United Kingdom & $\begin{array}{l}\text { Recruitment and } \\
\text { training costs }\end{array}$ & $2.4 \%-11.2 \%$ & $\mathrm{n} / \mathrm{a}$ \\
\hline Brown et al. (2001) & United Kingdom & $\begin{array}{l}\text { Recruitment and } \\
\text { training costs }\end{array}$ & $2.3 \%-11 \%$ & $55 \%-118 \%$ \\
\hline $\begin{array}{l}\text { Abowd and Kramarz } \\
\text { (2003) and Kramarz } \\
\text { and Michaud (2010) }\end{array}$ & France & $\begin{array}{l}\text { Training and external } \\
\text { hiring costs, no } \\
\text { internal hiring costs }\end{array}$ & $2.8 \%$ & $\mathrm{n} / \mathrm{a}$ \\
\hline Blatter et al. (2012a) & Switzerland & $\begin{array}{l}\text { Recruitment and } \\
\text { training costs }\end{array}$ & $3.3 \%$ & $244 \%$ \\
\hline $\begin{array}{l}\text { Muehlemann and } \\
\text { Pfeifer (2012) }\end{array}$ & Germany & $\begin{array}{l}\text { Recruitment and } \\
\text { training costs }\end{array}$ & $1.9 \%$ & $200 \%$ \\
\hline
\end{tabular}

Extended and updated table based on Manning (2011). 
alternative employers in a region that offer vacancies in the same or similar occupations and (ii) the overall level of employment protection legislation.

For Germany, Kriechel et al. (2014) show that labour market institutions matter and affect the training behaviour of firms. They find that firms with works councils have higher training investments during the training period of approximately $€ 3,500$ per year of training (which is to a large degree due to higher apprentice pay). However, these firms also have 20 percentage-point higher retention rates five years after training than comparable firms without works councils. Thus, the evidence for German firms shows that firms are more likely to be willing to bear an initial net investment in apprenticeship training if the expected tenure of former apprentices is sufficiently high - such that the investment pays off in the long run.

Moreover, Dustmann and Schönberg (2009) find that most firms that offer apprenticeship training in Germany were unionised. As the wage structure within unionised firms is more compressed - and unionised firms typically have lower employee turnover - firms can in turn expect higher post-training benefits for two reasons: first, because apprentices are more likely to remain with the training firm (which saves future recruitment costs), and second, because former apprentices may be paid less than the value of their productivity.

For Switzerland, Strupler and Wolter (2012) show that realised recrutive opportunity benefits for Swiss training firms range from CHF 6,000 to CHF 16,000 (small to large firms), suggesting that at least larger training firms can cover the sizeable net costs at the end of the apprenticeship training period, as they can expect an equivalent benefit from retaining their former apprentices. At the other end of the size distribution of firms, very small firms that are unable to retain their apprentices are particularly forced to rely on a net benefit at the end of the training period. Although larger firms are more likely to retain their former apprentices, they do not typically intend to achieve a $100 \%$ retention rate, as the training period also serves as a screening period, and permanent employment will only be offered to the best apprentices.

Demographic developments in many (but not all) European countries will lead to fewer young people entering the labour market and therefore create skill shortages in some areas. Such skill shortages will increase hiring costs for skilled workers and should consequently increase a firm's incentives to engage in apprenticeship training. However, the smaller cohorts of school leavers also reduce the pool of suitable apprentices and thereby increase the recruitment costs for apprentices and/or the training costs, as the quality of the firm-apprentice match will decrease. The combined effect of smaller cohorts of school leavers (increased hiring costs for skilled workers and increased training costs for apprentices) on the share of training companies is therefore ambiguous (see Blatter et al. 2012b). Empirical analyses of the impact of demographic movements on the provision of training have shown pro-cyclical movements and that firms do not proportionally adjust their demand for apprentices to changes in cohort size, meaning that a $1 \%$ increase in cohort size increases a firm's demand for apprentices by less than 1\% (see Muehlemann et al. 2009 and Schweri and Mueller 2007).

\section{Other long-term benefits}

Screening by training is thus an additional potential benefit from training apprentices, provided that employers cannot easily assess a worker's potential productivity. Given asymmetric information between firms regarding the true productivity of workers, 
training firms can exploit their informational advantage by retaining the most talented apprentices with above-average ability compared to those available on the external labour market and simultaneously pay them the average market wage (cf. Autor 2001, Cappelli 2004, Lange 2007).

In addition to having the opportunity to select "the best employees" that would not otherwise be available on the external labour market, firms may also be able to pay former apprentices a wage below the value of their marginal productivity, provided that labour markets are imperfect (Acemoglu and Pischke 1998, 1999a,b; Stevens 1994a). Thus, labour market frictions increase a firm's willingness to make a net investment in apprenticeship training (while at the same time reducing an apprentice's willingness to make such an investment), as the training firm will obtain part of the return from apprenticeship training. Labour market frictions potentially leading to imperfect labour markets include social partner agreements (collective bargaining), mobility costs of workers, moral hazard, monopsonies (see Muehlemann et al. 2013b) or the interaction between firm-specific and general skills (see Lazear 2009).

Apprenticeship training may also serve as a signal for good working conditions, thereby also facilitating the recruitment process for skilled workers from the external labour market (Backes-Gellner and Tuor 2010). More generally, apprenticeship training may increase a firm's reputation (e.g., social responsibility), which may indirectly increase profits (Sadowski 1980) through advantages on the product market. However, the latter benefits are difficult to measure, and there are therefore few empirical studies that address this issue. Niederalt (2005) argues that rather than the benefit from a positive reputation effect, social pressure might be the reason for the increase in a firm's supply of apprenticeship training. The latter is more likely to occur if a firm operates in a rural area with a low number of employers, clients and potential apprentices.

Finally, the skill mix or the combination of skills within a firm can be improved through apprentices. Many studies (for a literature review, see CEDEFOP 2011) have found that the share of employees with vocational degrees significantly increases overall labour productivity, although less so the profitability of firms. The combination of the two results (see, e.g., Mohrenweiser and Zwick 2009) could be interpreted as an indication that in most cases studied thus far, firms incurred net costs of training that are balanced by the increase in productivity, leading to a neutral short-term outcome on profitability.

In summary, there are numerous potential factors in addition to the productive contribution of apprentices during training that may generate additional returns to employers in the long run. However, such measures are typically very firm-specific and arise at various points in time. It is therefore not surprising that the existing literature does not provide much concrete empirical evidence on the extent to which training expenditures could be justified by the existence of such long-term benefits.

\section{Factors that affect the profitability of apprenticeship training: institutions and markets matter}

In this section, we identify the key factors that affect a firm's costs and benefits when offering apprenticeships. While a firm may be able to influence some of these factors, others lie (at least partially) outside its sphere of influence. The main parameters that determine whether apprenticeship training is profitable for a firm are: (i) training 
regulations, (ii) labour and product market competition, (iii) the pay structure within the firm (apprentice vs. unskilled vs. skilled pay), and (iv) the productive contribution of apprentices.

\section{Training regulations}

\section{Schooling days outside firms}

Training regulations directly affect the cost-benefit ratio of apprenticeship training. In particular, the number of days in vocational school (i.e., where most of the learning takes place), vacation time, and the length of an apprenticeship programme significantly affect the costs and benefits of offering apprenticeships. However, the number of schooling days not only reduces the potential benefits of training companies by reducing the days the apprentice can spend productively in the company, it can also reduce the costs of training or increase the benefit from training for the firm. If the skills learnt in school are a prerequisite for the apprentice's immediate skilled work in the company, the firm would have had to provide the training in these skills at their own costs or accept a lower productivity of their apprentices. Therefore, more school days may under some conditions even increase short-term benefits of firms and might also be preferable from a social perspective if the provision of training in school is more cost-effective (for example, due to economies of scale or the professional knowledge of teachers) than in firms.

\section{Firm-specific vs. general skills, standardisation and certification of skills}

Apprenticeship schemes that require the provision of general skills increase the labour market mobility of graduated apprentices (and vice-versa for firm-specific skills). For this reason, governments regulating apprenticeship training schemes typically emphasise larger shares of general skills in training curricula. ${ }^{7}$ The higher the share of general skills that have to be provided, the less willing (ceteris paribus) firms will be to make a net investment in apprenticeship training, as they fear the loss of their investments when apprentices can easily leave the company after training. From the perspective of potential apprentices, however, enrolling in a training scheme that primarily provides firm-specific skills will be less appealing to more talented individuals, as it will strongly limit future career opportunities outside the training firm. Therefore, if all training firms were to provide mainly firm-specific skills, apprenticeship training would become less attractive for prospective apprentices and impact the supply of talented youth, thereby also reducing the benefits enjoyed by training firms. If, however, the general reputation of apprenticeship training is high, not providing the required form, quantity or quality of skills could still be profitable for a firm. Therefore, the standardisation and certification of skills is an additional requirement for high levels of training provision and a high level of competencies in equilibrium is necessary (Acemoglu and Pischke 2000; Dustmann and Schönberg 2007). Thus, if training regulations require a high share of general education in apprenticeship training, apprentices will be willing to accept low pay during the training period - as long as their acquired skills will be certified to ensure these skills can be used productively with a large number of potential future employers.

\section{Duration of apprenticeship}

The length of an apprenticeship programme is a very important factor, as firms typically make most of the training net-investments at the beginning of an apprenticeship 
(Malcomson et al. 2003). When apprentices become more productive during the training programme, eventually reaching the same productivity level as that of skilled workers in the firm, the initial net-investments by firms can become net benefits. Thus, from the perspective of the firm, the benefit from training apprentices increases (ceteris paribus) in the length of the training programme. Moreover, firms will be more willing to make substantial training investments if there is a sufficient period to recoup that training investment, i.e., a sufficiently long period where the productivity of the apprentice exceeds apprentice pay.

However, from the perspective of the apprentices, long durations of training programmes may have an adverse effect on their enrolment probabilities. In this context, legal issues become important, e.g., as in the absence of a binding training contract, apprentices could simply leave the training firm after receiving the bulk of their training. Thus, the duration of a successful apprenticeship scheme should be set such that both firms and apprentices can generate a sufficiently high return on their training investment. The results from firm surveys in Germany, the United Kingdom and Switzerland show for apprenticeships of different training durations ( 2 to 4 years) that the average productivity of an apprentice in skilled tasks is always between $70 \%-85 \%$ in the middle of the last year of training (Beicht et al. 2004, Gambin et al. 2010, Muehlemann et al. 2007a). ${ }^{8}$ Thus, the observed training duration is chosen such that it corresponds on average to the time required to learn the occupation-specific competencies, i.e., the duration of an apprenticeship increases with the skill intensity of the corresponding training occupation.

\section{Labour market competition can reduce a firm's willingness to train}

A high density of competing firms in a regional labour market increases the pressure on firms to pay wages that are equal to the marginal productivity of skilled workers. Thus a firm's potential to recoup training investments by offering below-productivity pay to retained apprentices and saving on future recruitment costs decreases in more competitive markets, as the probability that a firm can retain its former apprentices is lower. The empirical evidence clearly shows that firms are less willing to offer firmsponsored training in dense local labour markets (Brunello and Gambarotto 2007 for the UK, Brunello and de Paola 2008 for Italy, Harhoff and Kane 1997 for Germany). However, the threat that a local competitor will poach apprentices after training will only have an adverse effect on the willingness to train if the expected net costs of apprenticeship training during training are positive (Muehlemann and Wolter 2011). If, however, firms can on average expect a net benefit from training during the training period, labour market competition has no adverse impact on the willingness to train. In contrast to competitive labour markets, monopsonistic labour markets (Muehlemann et al. 2013b) not only exert pressure on skilled wages but also on apprentices' wages, allowing firms to achieve positive returns from training investments more easily and thereby increasing a firm's willingness to offer training opportunities.

\section{Ambiguous effects of product market competition}

Monopolistic structures in the product market allow firms to train in more firmspecific skills and thus hedge investments in general skills. Although profits may be shared between the firm and the employees, a high degree of firm-specific training 
content may limit the labour market mobility of apprentices. Nonetheless, a reduced mobility of skilled workers with product- or technology-specific skills will increase a firm's willingness to make a net investment in training and offer apprenticeships. However, the absence of competition in the product market may also reduce a firm's need for a highly skilled workforce and decrease the gains from training investments. As there are two opposing theoretical effects, it remains an empirical question to determine which of the two effects is stronger. Bassanini and Brunello (2011) show that deregulation in European industries led, contrary to the predictions of some theoretical models, to an increase in training incidence.

The two factors - local labour and product market competition - also determine whether state interventions (i.e., subsidies) are necessary to balance the cost-benefit ratio of potential training firms to set incentives for the provision of training places (see discussion below).

\section{The role of apprentice pay, unskilled pay and skilled worker pay}

The pay structure has an important role in explaining the cost-benefit ratio of training, as a very high share of a firm's training expenditures are wage costs (either for apprentices or training personnel). Moreover, the benefits from training largely depend on the relative wages of apprentices, unskilled workers, and skilled workers. Obviously, a firm does not profit if an apprentice receives pay equal to the value of productivity. As firms also need to provide education and training to apprentices in the workplace, human capital theory predicts that apprentice pay must be lower than productivity during the training period if labour markets are competitive (Becker 1962). Consequently, apprentices finance their own training by accepting low pay, and they are willing to do so because of increased future wages due to their higher productivity, which again is due to the skills accumulated during training.

Table 3 provides an illustrative example for the calculation of an upper bound of apprentice pay depending on the time that an apprentice actually spends in the firm, the share of productive work while in the workplace, and how an apprentice performs skilled tasks compared to a skilled worker in the corresponding occupation. ${ }^{9}$ In Switzerland, a typical four-year apprenticeship in metalworking requires an apprentice to spend approximately $30 \%$ of a standard workweek away from the training establishment (i.e., 2 days per week in a vocational school or inter-industry courses). Additional training in the firm and non-productive activities account for approximately $40 \%$ of the time an apprentice spends in the workplace. Finally, while performing skilled tasks, apprentices are initially much less productive than fully trained workers (in this case, approximately $20 \%$, meaning that if it takes 12 minutes for a skilled worker to complete a task, an apprentice will require 60 minutes to complete the same task). As a result, assuming that an apprentice only performs skilled tasks, and not accounting for a firm's training expenditures, "fair" apprentice pay in relation to that of a skilled worker would be approximately $8 \%$ during the first year of training. As firms make considerable investments in apprentices, particularly during the first half of the training period, apprentice pay would in fact have to be negative to ensure that firms could be reimbursed for their training expenditures.

However, there are marked differences in training occupations, as shown in the example for the apprenticeship "cook". In this case, apprentices spend only one day per 
Table 3 How high would fair apprentice pay be? (Excluding firm training expenditures)

\begin{tabular}{lcccc}
\hline Mechanic in metalworking industry (4-year apprenticeship) & 1st year & 2nd year & 3rd year & 4th year \\
\hline Time in firm (i.e., not in vocational school) & $0.65(0.04)$ & $0.68(0.06)$ & $0.76(0.08)$ & $0.77(0.06)$ \\
Share of productive work while in firm & $0.57(0.02)$ & $0.72(0.19)$ & $0.85(0.14)$ & $0.90(0.09)$ \\
Productivity in skilled tasks compared to skilled worker & $0.20(0.15)$ & $0.47(0.16)$ & $0.63(0.13)$ & $0.81(0.09)$ \\
$\begin{array}{l}\text { Fair apprentice pay in relation to skilled worker pay (ignoring } \\
\text { firm's training costs) }\end{array}$ & $0.08(0.08)$ & $0.22(0.12)$ & $0.39(0.12)$ & $0.50(0.10)$ \\
\hline Cook (3-year apprenticeship) & $\mathbf{1 s t}$ year & 2nd year & 3rd year \\
\hline Time in firm (i.e., not in vocational school) & $0.79(0.06)$ & $0.81(0.03)$ & $0.81(0.03)$ \\
Share of productive work while in firm & $0.77(0.13)$ & $0.86(0.08)$ & $0.84(0.10)$ \\
Productivity in skilled tasks compared to skilled worker & $0.40(0.20)$ & $0.60(0.16)$ & $0.80(0.12)$ \\
Fair apprentice pay in relation to skilled worker pay (ignoring & $0.26(0.14)$ & $0.41(0.13)$ & $0.54(0.12)$ \\
firm's training costs) & & & & \\
\hline
\end{tabular}

Data from the $3^{\text {rd }}$ Swiss Cost-Benefit Survey (see Strupler and Wolter 2012), own calculations, standard errors in brackets

week in vocational school, spend more time in productive activities and are initially more productive in skilled tasks. However, the "fair" apprentice pay in relation to that of a skilled worker is still rather low (26\%) and does not take the training expenditures of the firm into account.

Table 3 essentially shows why apprentice pay must be lower in occupations where the initial productivity of apprentices is low. Moreover, low initial productivity may also be associated with a large investment from the firm, thereby exerting even more downward pressure on apprentice pay. Thus, low apprentice pay need not be a sign that firms exploit apprentices, but low apprentice pay may instead simply allow firms to offer advanced apprenticeship programmes without having to make significant net investments.

Therefore, particularly in countries with rather flexible labour markets and high posttraining apprentice mobility, sufficiently low apprentice pay may be a necessary condition for firms to provide high quality apprenticeships. Conversely, apprentice pay should be higher in occupations where apprentices are initially more productive and spend more time with productive work in the firm.

Apprentices typically spend some fraction of their time in the workplace engaged in unskilled (or low-skilled) tasks. As unskilled workers usually receive higher pay than apprentices, there is a possible concern that firms may exploit apprentices by offering low pay and having them perform unskilled tasks - while not providing a sufficient amount of training. A simulation-exercise in Wolter and Ryan $(2011,547)$ shows that firms could significantly increase their profits if apprentices were to only perform unskilled work. Thus, training regulations need to be in place to prevent the exploitation of apprentices. Ensuring that firms provide educational content in the workplace may, however, be a superior strategy for preventing the exploitation of apprentices, whereas the introduction of general and high minimum wages may in turn provide even more incentives for firms to use apprentices for unskilled labour and provide even less education in the workplace ${ }^{10}$.

However, if firms were to use apprentices solely for the purpose of cheap labour, apprenticeship programmes would become less appealing to young people, and they would then prefer to either opt for other types of education or directly enter the labour market as unskilled workers. 
Labour market institutions significantly impact the cost-benefit ratio, as unions, centralised bargaining agreements, or other forms of worker representations can directly impact the absolute or relative pay levels of different worker categories. Thus, as apprentice pay may be subject to a nationwide minimum wage, it may have a strong adverse effect on a firm's willingness to provide training. Table 4 shows that more than $62 \%$ of training costs in Germany are due to apprentice pay, whereas the corresponding figure is significantly lower in Switzerland (50\%), reflecting the different wage structures in the two countries ${ }^{11}$.

From a theoretical perspective, apprentice pay must be determined by the number of days that an apprentice spends in the training firm (and not at school or in other courses), the productivity of an apprentice when performing skilled work, and the intensity of general skills that the training firm provides in the workplace. Thus, to the extent that high quality apprenticeships may be associated with low apprentice pay, an additional emerging factor is the age of an apprentice: while low apprentice pay may be problematic for young adults, it can become an even more important issue for older apprentices. Therefore, in countries where apprenticeships are a potential form of training for young adults that have already acquired at least an upper-secondary education in a general schooling setting, instead of an upper-secondary education for adolescents, apprentice pay is an important issue for firms and can impede their willingness to train to such a degree that a functioning apprenticeship training market will not emerge.

\section{The productive contribution of apprentices}

The duration of a work placement is not necessarily directly linked to the productive value that an apprentice creates for the firm as apprentices may acquire certain skills not by actively participating in the production process but by simulating certain tasks in separate in-house or external learning centres. The time spent with unproductive tasks will, however, consequently limit the time available for productive tasks. To the extent that apprentices can learn certain skills only while not working, skills acquisition and the productive contributions of apprentices would be in competition with one another.

However, if skills acquisition and productive work are complements, and apprentices can only (or more effectively) learn certain skills in the work process, the involvement of apprentices in production becomes a mutually beneficial situation. Theoretically, it

Table 4 Composition of training costs in Germany (2007) and Switzerland (2009)

\begin{tabular}{lcccc}
\hline & \multicolumn{2}{c}{ Germany } & & \multicolumn{2}{c}{ Switzerland } \\
\cline { 2 - 2 } Training costs & all apprenticeships & & 3 year apprenticeships & 4 year apprenticeships \\
Apprentice pay & $62.1 \%$ & & $50 \%$ & $46 \%$ \\
Instructor pay & $21.5 \%$ & $39 \%$ & $39 \%$ \\
Training infrastructure and & $16.4 \%$ & $11 \%$ & $15 \%$ \\
material, and other costs & & & \\
Training benefits & $45.0 \%$ & $53 \%$ & $57 \%$ \\
From unskilled tasks & $55.0 \%$ & & & $51 \%$ \\
From skilled tasks & $0 \%$ & $1 \%$ & $2 \%$ \\
Other benefits & & & & \\
\hline
\end{tabular}

Source: Schönfeld et al. 2010 (Germany) and Strupler and Wolter 2012 (Switzerland). 
will be difficult to provide a final answer to this question, but the empirical observation of the positive skills development of German apprentices over the last decade - a period of increased involvement of apprentices in productive work (Jansen et al. 2012) - shows that skills acquisition and productive work can indeed be complements.

In addition to the question of working or not working while at the training firm, an important issue for apprentices and firms alike are the shares of skilled and unskilled work performed by apprentices. For the training firms, unskilled work can constitute a significant share of the total training benefit (see Table 4$)^{12}$, especially in markets where the relative wage of unskilled labour to skilled labour is high. However, as shown in the exposition of the cost-benefit model in section 2, it is important to note that a firm's benefit from skilled tasks does not simply equal the value of apprentices' time spent with skilled work but strongly depends on the productivity of apprentices relative to that of skilled workers (which is typically rather low in the beginning of training). Empirical observations show that firms would most likely not be able to achieve sufficient benefits to cover their training expenses from having apprentices solely perform skilled tasks. From the perspectives of apprentices (skills acquisition) and firms (training profitability), the timing and purpose of unskilled work is therefore decisive. Unskilled work should be mainly confined to the beginning of training, when the relative productivity of apprentices in skilled work is low and the development of non-cognitive skills such as punctuality, exactness, reliability or stamina (products of socialisation in the working world) are important.

\section{The impact of the costs and benefits of training on firm behaviour}

In this section, we summarize the literature that analyses to what extent the cost and benefits of apprenticeship training in the short term (during training) and the longer term (after training) influence a firm's willingness to train. We then discuss how these findings can provide important information on whether certain interventions, such as training subsidies, would constitute promising policy interventions to increase the supply of training places.

Muehlemann et al. (2007b) show that the net costs of training are an important determinant of a firm's decision to offer apprenticeships in Switzerland. They find that a 10\% increase in net training costs reduces a firm's training probability by $4.5 \%$. Wolter et al. (2006) show for Switzerland that while training firms on average generate a net benefit from apprenticeship training, non-training firms would face substantial net costs of training - which is the main reason why they refrain from offering apprenticeships. The latter study also shows that the finding that some firms have very high net training costs, while others generate net benefits, is not due to differences in gross training costs but rather a result of non-training firms being unable to provide a sufficient amount of productive tasks to apprentices - and therefore lack the benefits of training.

Similar analyses show that the net training costs during training play a less important role for German firms, as their willingness to offer apprenticeships mainly depends on benefits that arise after training (Muehlemann et al. 2010).

Furthermore, Blatter et al. (2012b) show that firms facing high (potential) external hiring costs supply more apprenticeship training positions, as training reduces or even eliminates the need to hire externally. They find that a one standard deviation increase in average hiring costs is associated with a 0.7 standard deviation increase in 
apprenticeship positions. Thus, firms that can save high future hiring costs for skilled workers are more inclined to train their own skilled workforce.

Finally, Muehlemann et al. (2013a) show that the expected net costs or net benefits from training (during the training period) also affect a firm's treatment of apprentices with different abilities. Firms on average expecting a net benefit from training are more inclined to compensate for a weak initial ability with additional training, whereas firms expecting net costs focus their resources on the most able apprentices - at the expense of the weaker ones. As a consequence, the dropout risk for apprentices is significantly lower if apprenticeship training is profitable on average, as a firm will be more likely to spend additional resources to prevent dropouts of weak apprentices. As long as dropouts occur early on, the costs for a firm may be limited, even if training results in net costs. However, a firm may expect that school-leavers without appropriate qualifications are more likely to drop out and thus refrain from offering an apprenticeship position in the first place.

\section{The role of training subsidies}

As the costs and benefits of training are - as shown - important factors that increase or decrease a firm's willingness to train, an important policy question is whether training subsidies would be a lever to increase the number of apprenticeship positions. There are different ways to subsidise apprenticeship training. In countries with a dual system (e.g., Austria, Germany, Switzerland), vocational schools are publicly funded, but employers pay training expenses and apprentices' salaries. However, some countries reimburse companies for their training expenditures (e.g., the Czech Republic, Finland, Norway, or the Slovak Republic) or subsidise all or part of the apprentices' salaries (e.g., for subsidies of adult apprentices aged more than 25 years in Denmark see Dohlmann Weatherall 2009). In some countries, new training firms, firms that take on additional apprentices compared to previous years, or firms that train apprentices with specific needs are eligible for onetime-payments (bonuses), subsidies or tax reductions. Finally, subsidizing apprenticeship training may also be initiated by the private sector, e.g. when training activities are cofinanced by both training and non-training firms that belong to a sectoral employer's association or a chamber of commerce (by means of membership fees). The rationale for such private sector solutions is on the one hand to lower a firm's training costs, and on the other hand to lower the benefits of free-riding for non-training firms, thereby increasing the likelihood that such firms will engage in training themselves.

However, the scarce evidence base on the effectiveness of training subsidies is inversely related to the popularity of such measures (although on CVET, see Mueller and Behringer 2012, p.12). There are at least three reasons that should caution against too high expectations. First, in the absence of adequate data on the cost and benefit of apprenticeship training, the causal impact of such subsidies on a firm's training activity remains unclear. For instance, many training firms may find training profitable even without subsidies, while other non-training firms may expect a net training investment even with training subsidies in place (and thus will not alter their training behaviour). In both cases, training subsidies would only result in a massive deadweight loss, while the number of apprenticeships remains unaffected. Second, even if training subsidies have a small causal effect on the provision of apprenticeships, i.e., some companies engage in training that would not have done so without the subsidies, high administrative costs associated with the redistribution of subsidies are likely to reduce the efficiency of 
such measures. Third, many interventions lead to unintended distortions in the labour market, like crowding out of private investments or the postponement of investments. The latter was, e.g., found in an evaluation of an incentive scheme in the Netherlands favouring workers after a certain age (see e.g. Leuven and Oosterbeek 2004). The effect of this policy was that the overall participation in the training increased for the targeted population but diminished in almost the same extent for the age group just before the target age. Therefore, interventions can also be accompanied by unintended compensatory actions for groups of workers that have not been included in the target population of the policy, which leads to an overall outcome that is unclear in its effectiveness, but costly in any case.

Observational evidence for Austria and simulations based on cost-benefit-data for Switzerland (Muehlemann et al. 2007b) show that training subsidies are not always a particularly efficient strategy to increase a firm's supply of training places. The main reason for this low efficiency is that subsidies generate substantial windfall gains for training companies, thus pricing marginal apprenticeship positions above the costs of a full-time school equivalent. The explanation for the inefficiency of subsidies in Switzerland is that training is already profitable for most training firms. Thus, training firms are unlikely to increase their supply of training positions (elasticity at the intensive margin), whereas the magnitude of the required subsidy for those firms that initially found training too expensive would have to be quite high for them to reconsider their training decision (elasticity at the extensive margin). In Denmark (see also Albaek 2009), however, apprentice pay subsidies appear to be more efficient, as an additional apprenticeship position comes at a cost of $1 / 6$ of the full-time education equivalent (Rasmussen and Westergaard-Nielsen 1999). Thus, the efficiency of training subsidies cannot be assessed uniformly and would have to be considered in light of the national (and even local) situation.

Strupler and Wolter (2013) analyse another type of incentive scheme in Switzerland. Firms applying for public contracts (in some cantons) are given preferential treatment if they train apprentices. This means that all other factors of an offer being equal, the fact that a company trains apprentices will increase its chances of winning the bid. The empirical evaluation shows that there is a significant association between a firm's willingness to train and the existence of such preferential treatment in public procurement. Moreover, it seems that the training quality in the firms operating in areas with such rules is identical to that of firms not subject to such rules. The advantage of such a scheme is that there are practically no direct costs for a government; however, legal issues (e.g., WTO guidelines) prevent the widespread application of such schemes, particularly for large contracts or contracts that are open to foreign competition. Nonetheless, such measures may be appropriate to provide incentives for small firms (in particular sectors such as crafts) that compete for relatively small public and local contracts.

\section{The special case of small and medium enterprises (SME)}

Many of the factors discussed above have a quite different relevance for small, medium or large enterprises. However, a better understanding of the training behaviour of SMEs is important because in many European countries, such firms account for up to $90 \%$ of all firms and most of the workplaces. Large firms that hire several apprentices each year 
will find it much easier to offer permanent employment contracts and career opportunities to a predetermined percentage of graduated apprentices than small firms. For that reason, large firms do not necessarily need to rely on net benefits during the training period. In addition, training several apprentices simultaneously may not only reduce training costs (economies of scale) but also enable large firms to employ apprenticeship training more efficiently as a screening device. Small companies, however, typically cannot train more than one apprentice at a time and are unable to subsequently employ a graduated apprentice if they wish to continue training apprentices. Therefore, small firms depend - compared to large firms - to a much greater extent on the possibility of covering all training expenses by the end of training period. Additionally, some fixed costs that are independent of the number of apprentices (such as regulatory costs) are more important for SMEs than for large companies. Finally, small companies are on average less attractive for potential (qualified) apprentices than large firms: First, small firms can offer fewer career opportunities for apprentices, and second, small firms typically offer lower apprentice pay (because of the lower pay level in small companies in general). Although lower pay reduces net training costs, it nevertheless constitutes an additional disadvantage compared to larger firms when it comes to recruiting the most talented apprentices.

Empirical observations show that very small companies in Switzerland (fewer than 10 employees) are significantly less engaged in apprenticeship training (see Table 5). Although the share of training firms with the category of very small companies is only one third compared to the corresponding share of firms with more than $100 \mathrm{em}$ ployees, they provide the same number of training places because of the very high share of small firms in the economy.

In other words, a large majority of very small companies will never engage in apprenticeship training, but full participation is not necessary for a functioning apprenticeship training market to provide a sufficient number of apprenticeship places.

One possible promising solution to facilitate the training participation among small companies are training networks, i.e., networks of two or more firms that jointly offer apprenticeship training. Such a training scheme is not only beneficial for the participating firms (because they can exploit their comparative advantages in skill-provision), but also for apprentices, as they can experience different production technologies across different firms during the course of their apprenticeship (Walther et al. 2005).

Another form of apprenticeship training that is beneficial to small (but also large) firms is an external training centre that typically provides basic training during the first one or two years of apprenticeship training. Such a training organisation essentially divides an apprenticeship into a first block of theoretical training and education in school (more common in the Nordic countries) and a second block where apprentices join the

Table 5 Share of training firms, net costs, and retention rate by firm size (Switzerland)

\begin{tabular}{cccccc}
\hline $\begin{array}{c}\text { Firm size } \\
\text { (number of } \\
\text { employees) }\end{array}$ & $\begin{array}{c}\text { Share of } \\
\text { training } \\
\text { firms }\end{array}$ & $\begin{array}{c}\text { Share among all } \\
\text { Swiss training } \\
\text { firms }\end{array}$ & $\begin{array}{c}\text { Share of } \\
\text { apprenticeships } \\
\text { in Switzerland }\end{array}$ & $\begin{array}{c}\text { Net benefit per } \\
\text { apprenticeship } \\
\text { (CHF) }\end{array}$ & $\begin{array}{c}\text { Retention rate } \\
\text { of former } \\
\text { apprentices }\end{array}$ \\
\hline $1-9$ & 0.26 & 0.46 & 0.30 & $18^{\prime} 400$ & 0.25 \\
$10-49$ & 0.42 & 0.34 & 0.32 & $14^{\prime} 400$ & 0.32 \\
$50-99$ & 0.59 & 0.09 & 0.10 & $13^{\prime} 200$ & 0.41 \\
$100+$ & 0.76 & 0.12 & 0.29 & -2300 & 0.47 \\
\hline
\end{tabular}

Data: from Strupler and Wolter (2012). Net benefits per apprenticeship are defined in chapter 2 ("The cost-benefit model"). 
training firm for longer periods (after having acquired a certain minimal amount of skills). While the training firm pays a membership fee for having apprentices participate in an external training centre, the main advantage of such schemes is that apprentices do not interrupt the production process of firms when apprentices are not yet very productive. Additionally, firms require less instruction time and thus do not need to hire additional personnel for training purposes. Thus, such schemes are particularly interesting for small and/or new firms and help to reduce the fixed costs associated with beginning apprenticeship training.

\section{Conclusions}

The provision of apprenticeship training by firms largely depends on economic factors, such as the costs and benefits associated with training apprentices during the training period, but also on the expected benefits that arise after the training period. Based on existing empirical evidence on the provision of dual apprenticeship programmes, the functioning of an apprenticeship system per se is not limited to specific labour market institutions. However, a balanced cost-benefit ratio during the training period is more important for a firm located in countries or regions with a high degree of labour market competition, ensuring that the provision of apprenticeships remains an attractive strategy.

This finding is also observed for SMEs, particularly for the very small ones. To offer apprenticeships, SMEs must therefore be able to rely on framework conditions that allow them to use apprentices with a high degree of flexibility in the work process and do not require them to employ apprentices as skilled workers after the apprenticeship period (otherwise, firms would not be able to offer new apprenticeship positions). Moreover, flexibility for firms would have to be paired with a high level of standardisation in training contents and curricula (at least at the national level) and external skills certification. Such measures would guarantee that apprentices can use their skills with other employers in the labour market, independent of where they completed their apprenticeships. As a result, apprenticeships would gain in attractiveness, which is important because otherwise potentially qualified apprentices may opt for other educational tracks if their expected return to enrolling in an apprenticeship programme is not sufficiently high. At the same time, particularly small firms would become more desirable apprenticeship providers for talented school leavers and other potential apprentices.

Policy makers will need more data on the costs and benefits of apprenticeship training for more European countries to be able to make informed decisions regarding the level of publicly financed vocational schooling, subsidies or tax deductions for training companies, minimum wages for apprentices or other types of labour market interventions. So far, only two countries provide representative and periodic data on the costs and benefits of apprenticeships (Germany and Switzerland). In the absence of such data, however, it will remain very difficult if not impossible to assess the effectiveness and efficiency of policy initiatives and interventions - ex ante as well as ex post.

\section{Endnotes}

${ }^{1}$ See also OECD (2010). Some programmes operating under the title of apprenticeship are work-based only (see, e.g., Ryan 2011). These "on-the-job" training programmes are primarily firm-specific, non-standardised forms of training or labour market programmes for the unemployed and will not be considered in this paper. 
2 As for other forms of education, the expectation that vocational education and training will also lead to positive externalities for the society as a whole, or reduce negative externalities that arise from low levels of education, provides a rationale for public co-financing of education (see e.g. CEDEFOP 2013). Public financing may include subsidizing a firm's training investments or the public provision of vocational schooling. In either case, public financing reduces a firm's training costs, making a firm's training provision more profitable and thus also more attractive.

${ }^{3}$ In 2011, the OECD published results from a survey on the treatment of firm costs for vocational education and training in the national statistics of member states (see also Figure 1): "Among countries with some form of dual educational systems, only Germany, Switzerland and, to some extent, the Netherlands, conduct surveys about private expenditure by employers. In a number of countries, such as the Czech Republic, Finland, Norway, and the Slovak Republic, workplace training is directly financed by the government, or firms are reimbursed for their expenses; thus private expenditures are implicitly included in public expenditures reported in the indicators for most of these countries." (OECD 2011, 234) "However, 11 out of 17 countries with an important dual system - Australia, Austria, Denmark, Estonia, France, Hungary, Iceland, Luxembourg, the United Kingdom and Russia - do not currently include private expenditure by enterprises that relate to these programs in the financial indicators published in Education at a Glance, mainly because of the lack of corresponding data of firm expenditures." (OECD 2011, 235).

${ }^{4}$ Thus, if it takes an apprentice twice as long to complete a certain task as a skilled worker, the relative productivity is $50 \%$, meaning that the value to the firm of having an apprentice performing skilled work is half of the wage costs associated with employing a skilled worker.

${ }^{5}$ The first surveys for Germany were carried out in the 1970s and 1980s but are not listed here for reasons of space.

${ }^{6}$ Firms are also able to offer training profitably in the recently introduced 2-year training programmes with a federal certificate (Fuhrer and Schweri 2010).

${ }^{7}$ Pfeifer et al. (2011) estimate the ratio of general to firm-specific skills in the workplace in a typical German apprenticeship to be approximately 88 to 12 per cent.

${ }^{8}$ There is considerable variation in the length of an apprenticeship across countries and skill levels, typically ranging from 1-4 years.

9 The data used to calculate the "fair pay" in table 3 comes from the $3^{\text {rd }}$ Cost-Benefit survey on apprenticeship training in Switzerland (see Strupler and Wolter 2012). The survey covered a representative sample of almost 2,500 training companies. The data used for tables 3, 4 and 5 is also described in more detail and in English in Dionisius et al. (2009). Most of the variance in the data stems from differences in the firmspecific training models and also the quality of trainees. This is particularly the case in the second and third year of training for mechanics, where some firms still follow a theory based approach for the second year of training, which leads to a jump in productivity in the third year, whereas other firms already extensively use their apprentices for productive work during the second year.

10 The relative pay of apprentices in the United Kingdom is approximately $60 \%$, whereas it is only 10-36\% in Switzerland and 20-45\% in Germany (Brunello 2009). However, the combined share of general education in the workplace and off-job 
education in the UK is $0 \%$, whereas it is estimated to be $53-78 \%$ in Germany and $30-50 \%$ in Switzerland.

${ }^{11}$ Kriechel et al. (2014) show that apprentice pay in Germany is strongly associated with worker representation at the firm level, as firms with a works council offer on average more than $10 \%$ higher apprentice pay than other firms.

12 The marked differences in the shares of benefits from unskilled tasks between the two countries can be explained by the fact that more German firms follow the so-called investment oriented training strategy, whereas the majority of Swiss firms uses a production oriented training strategy (a more detailed description of these differences can be found in Muehlemann et al. 2010).

${ }^{13}$ For the Netherlands, only estimations for the total of training costs for firms training apprentices exist.

Competing interests

The IZA Journal of Labor Policy is committed to the IZA Guiding Principles of Research Integrity. The authors declare that they have observed these principles.

\section{Acknowledgments}

A first version of this paper was initially written on the request of the DG EAC of the EU and was circulated as an EENEE working paper (No.16, October 2013). The authors would like to thank the anonymous referee. Opinions expressed in this article are those of the authors alone and do not necessarily represent the point of view of the European Commission. The authors acknowledge comments and advice on earlier versions of this paper by Ludger Woessmann, Sophia Eriksson-Waterschoot, Ulrich Sauer and Nina Smith.

Responsible editor: Juan F. Jimeno

\section{Author details}

${ }^{1}$ University of Munich (LMU), Munich, Germany. ${ }^{2}$ University of Bern, CESifo, Bern, Switzerland. ${ }^{3}$ IZA - Institute for the Study of Labor, Bonn, Germany.

Received: 6 June 2014 Accepted: 10 October 2014

Published: 28 Nov 2014

\section{References}

Acemoglu D, Pischke JS (1998) Why do firms train? Theory and evidence. Q J Econ 79-119

Acemoglu D, Pischke JS (1999a) Beyond Becker: Training in imperfect labour markets. Econ J 108:F112-F142

Acemoglu D, Pischke JS (1999b) The structure of wages and investment in general training. J Polit Econ 107(3):539-572

Acemoglu D, Pischke JS (2000) Certification of training and training outcomes. Eur Econ Rev 44(4-6):917-927

Albaek K (2009) The Danish apprenticeship system, 1931-2002: The role of subsidies and institutions. Appl Econ Q 55(1):39-60

Autor D (2001) Why do temporary help firms provide free general skills training? Q J Econ 116(4):1409-1448

Backes-Gellner U, Tuor SN (2010) Avoiding labor shortages by employer signaling - on the importance of good work climate and labor relations. Ind Labor Relat Rev 63(2):271-286

Bassanini A, Brunello G (2011) Barriers to entry, deregulation and workplace training: A theoretical model with evidence from Europe. Eur Econ Rev 55(8):1152-1176

Becker G (1962) Investment in human capital: a theoretical analysis. J Polit Econ 70(5):9-49

Beicht U, Walden G, Herget H (2004) Kosten und Nutzen der betrieblichen Berufsausbildung in Deutschland. Bundesinstitut für Berufsbildung. Berichte zur beruflichen Bildung, Heft 264. Bielefeld, Bertelsmann

Blatter M, Muehlemann S, Schenker S (2012a) The costs of hiring skilled workers. Eur Econ Rev 56(1):20-35

Blatter M, Muehlemann S, Schenker S, Wolter SC (2012b) Hiring Costs of Skilled Workers and the Supply of Firm-Provided Training, IZA Discussion Paper, No. 6344

Brown D, Dickens R, Machin S, Gregg P, Manning A (2001) Everything Under a Fiver: Recruitment and Retention in Lower Paying Labor Markets. Joseph Rowntree Foundation, London

Brunello G (2009) The effect of economic downturns on apprenticeships and initial workplace training: A review of the evidence. Empir Res Vocat Educ Train 1(2):145-171

Brunello G, de Paola M (2008) Training and the density of economic activity: Evidence from Italy. Lab Econ 15(1):118-140

Brunello G, Gambarotto F (2007) Agglomeration effects on employer-provided training: Evidence from the UK. Reg Sci Urban Econ 37(1):1-22

Cappelli P (2004) Why do employers pay for college? J Econometrics 121(1-2):213-241

CEDEFOP (2011) The Impact of Vocational Education and Training on Company Performance. Publications Office of the European Union, Luxembourg

CEDEFOP (2013) Benefits of Vocational Education and Training in Europe for People, Organisations and Countries. Publications Office of the European Union, Luxembourg

Dionisius R, Muehlemann S, Pfeifer H, Walden G, Wenzelmann F, Wolter SC (2009) Cost and benefit of apprenticeship training: a comparison of Germany and Switzerland. Appl Econ Q 55(1):7-37 
Dohlmann Weatherall C (2009) Do subsidized adult apprenticeship increase the vocational attendance rate? Appl Econ Q 55(1):61-82

Dustmann C, Schönberg U (2007) Apprenticeship Training and Commitment to Training Provision, vol No. 32, Universities of Zurich and Bern: Leading House Working Paper Series

Dustmann C, Schönberg U (2009) Training and union wages. Rev Econ Stat 91(2):363-376

Fuhrer M, Schweri J (2010) Two-year apprenticeships for young people with learning difficulties: a cost-benefit analysis for training firms. Empir Res Vocat Educ Train 2(2):107-126

Gambin L, Hasluck C, Hogarth T (2010) Recouping the costs of apprenticeship training: employer case study evidence from England. Empir Res Vocat Educ Train 2(2):127-146

Harhoff D, Kane TJ (1997) Is the German apprenticeship system a panacea for the U.S. labour market? J Popul Econ 10:171-196

Jansen A, Strupler Leiser M, Wenzelmann F, Wolter SC (2012) The Effect of Labor Market Regulations on Training Behavior and Quality: the German Labor Market Reform as a Natural Experiment, vol No. 83, Universities of Zurich and Bern: Leading House Working Paper Series

Kriechel B, Muehlemann S, Pfeifer H, Schuette M (2014) Works councils, collective bargaining and apprenticeship training. Ind Relat 53(2):199-222

Lange F (2007) The speed of employer learning. J Labor Econ 25(1):1-36

Lassnigg L, Steiner P (1997) Die betrieblichen Kosten der Lehrlingsausbildung, Kammer für Arbeiter und Angestellte für Wien, Materialien zu Wirtschaft und Gesellschaft Nr. 67

Lazear E (2009) Firm-specific human capital: a skill-weights approach. J Polit Econ 117(5):914-940

Leuven $\mathrm{E}$, Oosterbeek H (2004) Evaluating the effect of tax deductions on training. J Labor Econ 22(2):461-488

Malcomson JM, McGaw JW, McCormick B (2003) General training by firms, apprentice contracts, and public policy. Eur Econ Rev 47:197-227

Manning A (2006) A generalised model of monopsony. Econ J 116:84-100

Manning A (2011) Imperfect competition in the labor market. In: Ashenfelter O, Card D (eds) Handbook of Labor Economics, vol 4., pp 973-1041, Chapter 11

Mohrenweiser J, Zwick T (2009) Why do firms train apprentices? The net cost puzzle reconsidered. Lab Econ 16(5):631-637

Muehlemann S, Pfeifer H (2012) The Structure of Hiring Costs in Germany, vol No. 77, Universities of Zurich and Bern: Leading House Working Paper Series

Muehlemann S, Wolter SC (2011) Firm-sponsored training and poaching externalities in regional labor markets. Reg Sci Urban Econ 41(6):560-570

Muehlemann S, Schweri J, Winkelmann R, Wolter SC (2007b) An empirical analysis of the decision to train apprentices. Lab Rev Lab Econ Ind Relat 21(3):419-441

Muehlemann S, Wolter SC, Wüest A (2009) Apprenticeship training and the business cycle. Empir Res Vocat Educ Train 1(2):173-186

Muehlemann S, Pfeifer H, Walden G, Wenzelmann F, Wolter SC (2010) The financing of apprenticeship training in the light of labor market regulations. Lab Econ 17(5):799-809

Muehlemann S, Braendli R, Wolter SC (2013a) Invest in the Best or compensate the Weak? An Empirical Analysis of the Heterogeneity of Firm's Provision of Human Capital. Evid baseHum Resource Manag 1(1):80-95

Muehlemann S, Ryan P, Wolter SC (2013b) Monopsony power, pay structure and training. Ind Labor Relat Rev 66 (5):1095-1112

Mueller N, Behringer F (2012) Subsidies and Levies as Policy Instruments to Encourage Employer-Provided Training, OECD Education Working Paper No. 80. OECD, Paris

Mühlemann S, Wolter SC, Fuhrer M, Wüest A (2007a) Lehrlingsausbildung - Ökonomisch Betrachtet. Zürich/Chur, Rüegger Verlag

Niederalt M (2005) Bestimmungsgründe des betrieblichen Ausbildungsverhaltens in Deutschland, Discussion Paper No. 36. Friedrich-Alexander-Universität Erlangen-Nürnberg

OECD (2010) Learning for Jobs. OECD, Paris

OECD (2011) Education at a Glance 2011. OECD, Paris

Pfeifer H, Wenzelmann F, Schönfeld G (2009) Ausbildungskosten und das Übernahmeverhalten von Betrieben - Ein Vergleich der BIBB-Kosten- und Nutzenerhebungen der Jahre 2000 und 2007. Sozialer Forschritt 6-7/2010

Pfeifer H, Schönfeld G, Wenzelmann F (2011) How large is the firm-specific component of German apprenticeship training? Empir Res Vocat Educ Train 3(2):85-104

Rasmussen AR, Westergaard-Nielsen N (1999) The impact of subsidies on the number of new apprentices. Res Lab Econ 18:359-375

Ryan P (2011) Apprenticeship: between Theory and Practice, School and the Workplace, vol No. 64, Universities of Zurich and Bern: Leading House Working Paper Series

Sadowski D (1980) Berufliche Bildung und Betriebliches Bildungsbudget. Poeschel, Stuttgart

Schönfeld, Gudrun, Wenzelmann F, Dionisius R, Pfeifer H, Walden G (2010) Kosten und Nutzen der dualen Ausbildung aus Sicht der Betriebe, Bundesinstitut für Berufsbildung (BIBB)

Schweri J, Mueller B (2007) Why has the share of training firms declined in Switzerland? J Lab Market Res (ZAF) 2+3(Issue 3):149-167

Schweri J, Muehlemann S, Pescio Y, Walter B, Wolter SC, Zuercher L (2003) Kosten und Nutzen der Lehrlingsausbildung aus der Sicht Schweizer Betriebe. Ruegger Verlag, Chur/Zürich

Stevens M (1994a) A theoretical model of on-the-job training. Oxf Econ Paper 46(4):537-562

Stevens M (1994b) An investment model for the supply of training by employers. Econ J 104:556-570

Strupler M, Wolter SC (2012) Die duale Lehre eine Erfolgsgeschichte - auch für Betriebe. Ergebnisse der dritten Kosten-Nutzen-Erhebung der Lehrlingsausbildung aus der Sicht der Betriebe. Glarus/Chur, Rüegger Verlag

Strupler M, Wolter SC (2013) Kann man mit dem öffentlichen Beschaffungswesen Lehrstellen Fördern? vol No. 85 Universities of Zurich and Bern: Leading House Working Paper Series 
Walther B, Schweri J, Wolter SC (2005) Shall I train your apprentice? An empirical investigation of outsourcing of apprenticeship training in Switzerland. Educ + Train 47(4/5):251-269

Wolter SC (2008) Ausbildungskosten und -nutzen und die betriebliche Nachfrage nach Lehrlingen. Perspektiven der Wirtschaftspolitik 9(S1):90-108

Wolter SC, Ryan P (2011) Apprenticeship. In: Hanushek R, Machin S, Woessmann L (eds) Handbook of Economics of Education, 3rd edn. Elsevier, Amsterdam

Wolter SC, Muehlemann S, Schweri J (2006) Why some firms train apprentices and many others do not. Ger Econ Rev 7(3):249-264

10.1186/2193-9004-3-25

Cite this article as: Muehlemann and Wolter: Return on investment of apprenticeship systems for enterprises:

Evidence from cost-benefit analyses. IZA Journal of Labor Policy 2014, 3:25

Submit your manuscript to a SpringerOpen ${ }^{\circ}$ journal and benefit from:

- Convenient online submission

- Rigorous peer review

- Immediate publication on acceptance

- Open access: articles freely available online

- High visibility within the field

Retaining the copyright to your article

Submit your next manuscript at $\boldsymbol{\sim}$ springeropen.com 